Balsam poplar is the most versatile, in terms of the means available for regeneration, species in Alaska. Seed regeneration was best on mineral soil, and root sucker production benefited from removal of the forest floor. Broken branch segments must be buried during harvesting to produce new trees. Thus the probability of regeneration by these means appears to be increased by surface distur-

\section{References}

Day, M.W., and F.H. Vogel. 1944. Silviculture and utilization of balsam poplar. J. For. 42: 512-514.

Fowells, H.A. 1965. Silvics of forest trees of the United States. USDA For. Serv. Agric. Handb. No. 271. 762 p.

Kozlowski, T.T. 1971. Growth and development of trees. Vol. 1, Seed germination, ontogeny, and shoot growth. Academic Press, New York. $443 \mathrm{p}$.

Maini, J.S. 1968. Silvics and ecology of Populus in Canada. p. 20-69. In Maini, J. S. and J.H. Cayford. (Ed.) Growth and utilization of Poplars in Canada. Can. Dep. Forest. and Rural Develop. Forest. Branch, Publ. No. 1205.

Schier, G.A. and R.B. Campbell. 1976. Difference among Populus species in suckering from root segments and rooting of sucker cuttings. Can. J. For. Res. 6: 253-261.

Van Cleve, K., L.A. Viereck, and R. Schlentner. 1971. Accumulation of nitrogen in alder (Alnus) ecosystems near Fairbanks, Alaska. Arct. and Alp. Res. 3 (2): 101-114. bances. Increased surface disturbance could be accomplished by concentrating logging during snow-free periods and/or post harvest site preparation.

The fourth means of regeneration, stump sprouting, did not result in tree for tree replacement. Dormant season harvesting appeared to be most desirable if maximum sprout production is desired.
Viereck, L.A. 1970. Forest succession and soil development adjacent to the Chena River in interior Alaska, Arct. and Alp. 2(1):1-26.

Viereck, L.A. and M.J. Foote. 1970. The status of Populus balsamifera and P. trichocarpa in Alaska. Can. Field Nat. 84: 169-173.

Wolff, J.O. and J.C. Zazada. 1979. Moose habitat and forest succession on the Tanana River floodplain and Yukon-Tanana upland. Proc. N. Am. Moose Conf. and Workshop No. 15:213-244.

Zasada, J.C. and G.A. Schier. 1973 Aspen root suckering in Alaska: effect of clone, collection date and temperature. Northwest Sci. 47 (2): 100-104.

Zasada, J.C. and L.A. Viereck. 1975. The effect of temperature and stratification on germination in selected members of the Salicaceae in interior Alaska. Can. J. For. Res. 5: 333-337.

\title{
Survival and Growth of Bullet, Styroplug and Bareroot Seedlings on Mid-Elevation Sites in Coastal British Columbia
}

\author{
by \\ J.T. Arnott1
}

\begin{abstract}
A trial was established over 2 successive years at two midelevation locations on southern Vancouver Island to assess and compare the field performance of a) 1-0 seedlings grown in Walters' bullets, b) 1-0 plug seedlings grown in BC/CFS Styroblocks, and c) conventional 2-0 bareroot stock of Pseudotsuga menziesii and. Tsuga heterophylla.

Five years after planting, average survival rates for $P$. menziesii were a) 77 , b) 84 and c) $81 \%$, and for $T$. heterophylla, a) 69 , b) 87 and c) $63 \%$. Average fifth year height on these mid-elevation sites was a) 51 , b) 62 and c) $72 \mathrm{~cm}$ for $P$. menziesii, and a) 63 , b) 67 and c) $57 \mathrm{~cm}$ for $T$. heterophylla. The results indicate that significantly better field performance can be obtained using 1-0 styroplug seedlings for $T$. heterophylla rather than conventional 2-0 bareroot stock. Such statistically significant differences were not evident for $P$. menziesii.
\end{abstract}

\section{Résumé}

Un test fut établi et poursuivi durant 2 années consécutives sur deux sites d'élévation moyenne au sud de l'île de Vancouver pour établir et comparer le rendement sur le terrain des:

a) semis 1.0 cultivés dans les douilles du type Walter; b) semis 1.0 cultivés dans les contenants en "Styroblocks" du $\mathrm{BC} / \mathrm{CFS}$ et

c) semis traditionnels $2 \cdot 0$, utilisés à racines nues du Pseudotsuga menzeisii et de Tsuga heterophylla.

Cinq ans après la plantation, les taux de survie moyens pour le Pseudotsuga furent pour a) $77 \%$, b) $84 \%$ et c) $81 \%$ tandis que pour Tsuga, ceux-ci furent pour a) $69 \%$, b) $87 \%$ et c) $63 \%$. La hauteur moyenne quinquennale sur ces sites d'élévation moyenne fut de a) $51 \mathrm{~cm}$; b) $62 \mathrm{~cm}$ et c) $72 \mathrm{~cm}$ pour Pseudotsuga et a) $63 \mathrm{~cm}$; b) $67 \mathrm{~cm}$ et c) $57 \mathrm{~cm}$ pour Tsuga. Ces résultats indiquent clairement qu'on obtient un meilleur rendement sur le terrain en utilisant des semis 1-0 issus de contenants en "Styroblocks" pour Tsuga heterophylla plutôt que de prendre les semis traditionnels $2-0$ à racines nues. Cependant de telles différences ne furent pas aussi évidentes pour le Pseudotsuga menziesii.

\section{Introduction}

Field trials of container reforestation systems have been made in British Columbia since 1967 (Arnott 1973). Initial inTPacific Forest Research Centre, Canadian Forestry Service, 506 W. Burnside Rd. Vic-
toria, B.C. V8Z 1 M5 
vestigations were with seedlings grown and planted in solidwalled containers on low elevation coastal sites on southern Vancouver Island (Arnott 1971, 1975), but subsequent development of the BC/CFS Styroblock Reforestation System "plug" concept broadened the investigations to include the styroplug seedling. The objective of the present trial was to assess and compare the survival and growth of Douglas-fir (Pseudotsuga menziesii (Mirb.) Franco) and western hemlock (Tsuga heterophylla (Raf.) Sarg.) bullet, styroplug and bareroot seedlings, planted over 2 successive years on two mid-elevation locations on southern Vancouver Island. One-year-old seedlings grown in the 11-cm Walters' bullet$^{2}$ (Walters 1969) and the BC/CFS Styroblock $2^{3}$ (Sjoberg 1974) were compared with conventional 2-0 bareroot stock over a 5-year period from the time of planting.

\section{Seedling Culture}

All container stock was grown in the Pacific Forest Research Centre nursery, Victoria, B.C. The growing medium for the bullets and styroblocks contained, per $m^{3}, 3$ parts peat and 1 part horticultural grade vermiculite and 3 $\mathrm{kg}$ Dolomite lime (1.4 $\mathrm{mm}$ mesh and finer). Douglas-fir and western hemlock seeds were sown in early April, covered with a layer of granite grit ( 2 to $4 \mathrm{~mm}$ ) and misted frequently. Following germination indoors, the containers were transferred to an outdoor shadehouse nursery (Sjoberg 1974) with shadecloth which provided 20 and $46 \%$ shade to the Douglas-fir and western hemlock seedlings, respectively; in keeping with the shade tolerance of the two species.

Irrigation water and water soluble fertilizers were applied, using fixed sprinklers. In 1971, the seedlings were fertilized twice weekly with Plant Products Ltd 4 . 28-14-14 (180 g/kl) in the summer and $15-15-30(120$ to $370 \mathrm{~g} / \mathrm{kl})$ in the fall. Water was applied when needed during hot, dry weather. Bullet seedlings were also sub-irrigated occasionally to maintain high soil moisture levels.

In 1972, the fertilizer regimes were modified as follows. Plant Products Ltd. ${ }^{4}$ 10-52-10 was applied at $625 \mathrm{~g} / \mathrm{kl} 2$ weeks following germination in the spring and again throughout the fall. Associated research had demonstrated that application of additional phosphorus during the autumn substantially increased seedling dry weight (Van Eerden 1974). Throughout June and July, $310 \mathrm{~g} / \mathrm{kl}$ of 28-14-14 was applied twice a week, and supplemented twice a month with $310 \mathrm{~g} / \mathrm{kl}$ of ammonium nitrate.

The trees were held outside in the nursery throughout the winter and were fed $10-52-10$ at $625 \mathrm{~g} / \mathrm{kl}$ from one to three times a month until planted. Morphological characteristics of the container-grown seedlings are shown in Table 1.

Seed source of container-grown and bareroot seedlings were matched to the planting location. The bareroot stock was grown at the British Columbia Ministry of Forests' nursery at Duncan, $60 \mathrm{~km}$ north of Victoria. Standard procedures for growing 2-0 Douglas-fir and hemlock were used (Van den Driessche 1969). Respective age of the 1-0 container and the $2-0$ bareroot seedlings was approximately 52 and 106 weeks. Bareroot seedlings were lifted in February and stored at $2^{\circ} \mathrm{C}$ until outplanted. Average shoot length of the Douglas-fir and western hemlock bareroot stock was 27 $\mathrm{cm}$ and $22 \mathrm{~cm}$, respectively.

\section{Study Areas}

The two experimental areas were located in the upper valleys of the Robertson (Lat. $48^{\circ} 39^{\prime}$, Long. $124^{\circ} 03^{\prime}$ ) and Leech (Lat. $48^{\circ} 32^{\prime}$, Long. $123^{\circ} 48^{\prime}$ ) rivers in southern Vancouver Island. North and south aspects were selected at each location but a wildfire subsequently destroyed the

\footnotetext{
2More commonly referred to in the literature as the 4 1/2-in Walters' bullet; gross cavity volume $22 \mathrm{~cm}^{3}$

${ }^{3}$ Gross cavity volume $40 \mathrm{~cm}^{3}$.

${ }^{4}$ Plant Products Ltd., Bramalea, Ontario.
}

series of plots established on the south aspect at Robertson River, eliminating the effect of aspect at that location.

Both areas fell within the coastal western hemlock biogeoclimatic zone. The Robertson River area, at an elevation of $640 \mathrm{~m}$, was transitional to the east Vancouver Island montane wetter maritime coastal western hemlock variant (CWHb5), while the Leech River area, at an elevation of 550 $\mathrm{m}$, fell within the east Vancouver Island drier maritime coastal western hemlock variant (CWHb3) (Klinka et al. 1979). Mean annual precipitation at the Robertson River is $3,000 \mathrm{~mm}$, less than $10 \%$ of which falls during June, July and August (Korelus and Lewis 1976). The Leech River area has an annual precipitation of $2500 \mathrm{~mm}, 5 \%$ of which falls during June, July and August (Roemer and Korelus 1975).

In both areas, the soils are well drained mini to orthic humo-ferric podzols (Korelus and Lewis 1976). Average soil depth to glacial till is $60-80 \mathrm{~cm}$. At Robertson River, the north-aspect slope is steep $(50 \%)$ with a substantial amount of surface soil erosion. At Leech River, slopes are moderate (21-40\%).

Prior to logging, in $1965-66$, both areas supported mature stands of Douglas-fir and western hemlock admixed with amabilis fir (Abies amabilis (Dougl.) Forbes) and western red cedar (Thuja plicata Donn). Slash burning after logging reduced the surface organic layers to $3-4 \mathrm{~cm}$ and resulted in a dense vegetative cover of fireweed (Epilobium augustifolium) by the time the plots were established in 1972 and 1973.

\section{Planting}

Sites were planted as early in the spring as conditions allowed; i.e., when the area was accessible and all snow had melted from the site. The Leech River area was planted in March of 1972 and 1973. The higher elevation of the Robertson River area ( 640 m vs. $550 \mathrm{~m}$ ) and later snow melt, resulted in later planting dates there. In 1973, planting was completed by mid-April. However, continued heavy snow fall in 1972 delayed planting until May 9 .

All container grown stock was planted without interim cold storage. The bullet stock was planted with a "gun" (Walters 1969). The plug seedlings were extracted from the styroblocks on site and dibble-planted. All bareroot stock was mattock-planted.

\section{Experimental design}

The field trials used a randomized block with split plot design. Within each block, years were randomly assigned to the split plots within which the three stock types were randomly located. At each location, a series of three randomized blocks were set out on a south and north-facing aspect, alternating Douglas-fir and western hemlock plantations along the hillside. In each plantation, 50 seedlings of each stock type were planted at a spacing of $2 \times 1 \mathrm{~m}$ for each species each year.

Survival and height growth measurements were made after the first, second, third and fifth growing seasons on all seedlings and the data were subjected to analysis of variance and multiple range tests to examine treatment effects (Steel and Torrie 1960).

\section{Results and Discussion Douglas-fir}

There were significant differences in seedling survival between stock types at Robertson River (Table 2), where bareroot stock had significantly higher survival than styroplug seedlings (Fig. 1). However, there was a highly significant year-of-outplanting effect here. Styroplug seedlings from the first outplanting in 1972 suffered high initial mortality, while those planted the following year did not. 
Table 1. Characteristics of container-grown seedlings at the time of planting

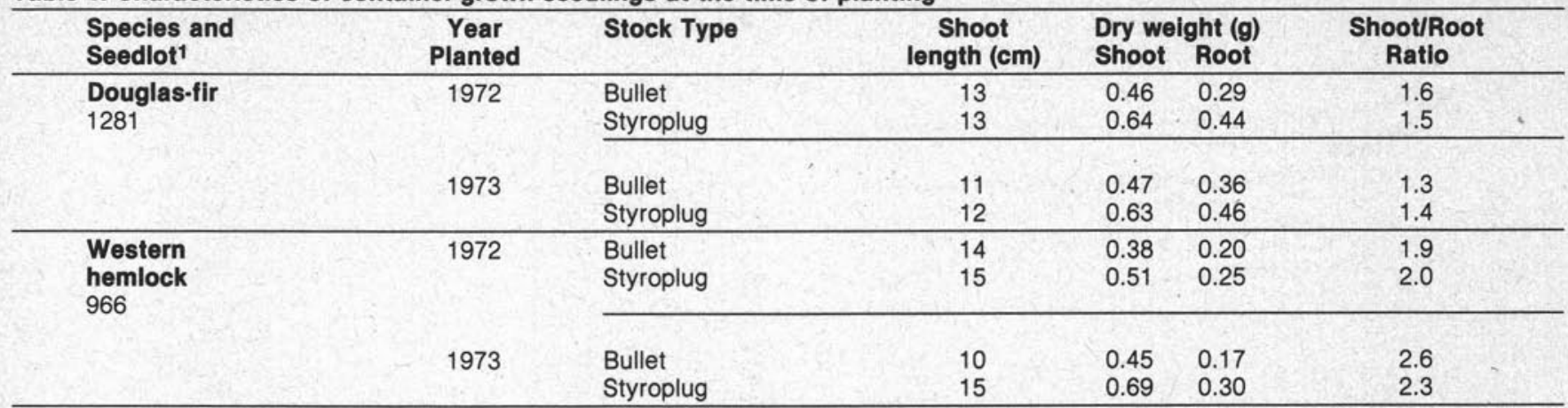

1B.C. Ministry of Forests' registered seedlot numbers.

\section{DOUGLAS - FIR : ROBERTSON (NORTH)}
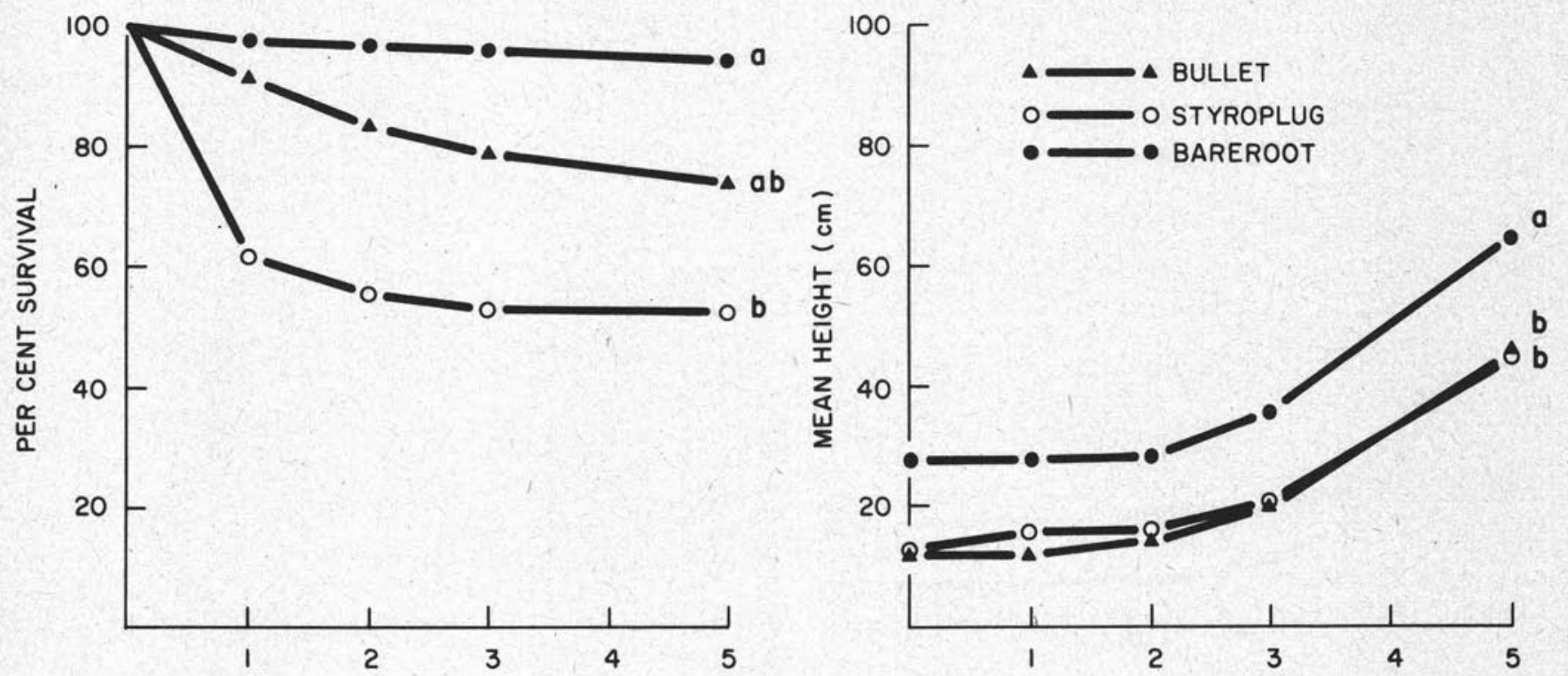

WESTERN HEMLOCK : ROBERTSON (NORTH)
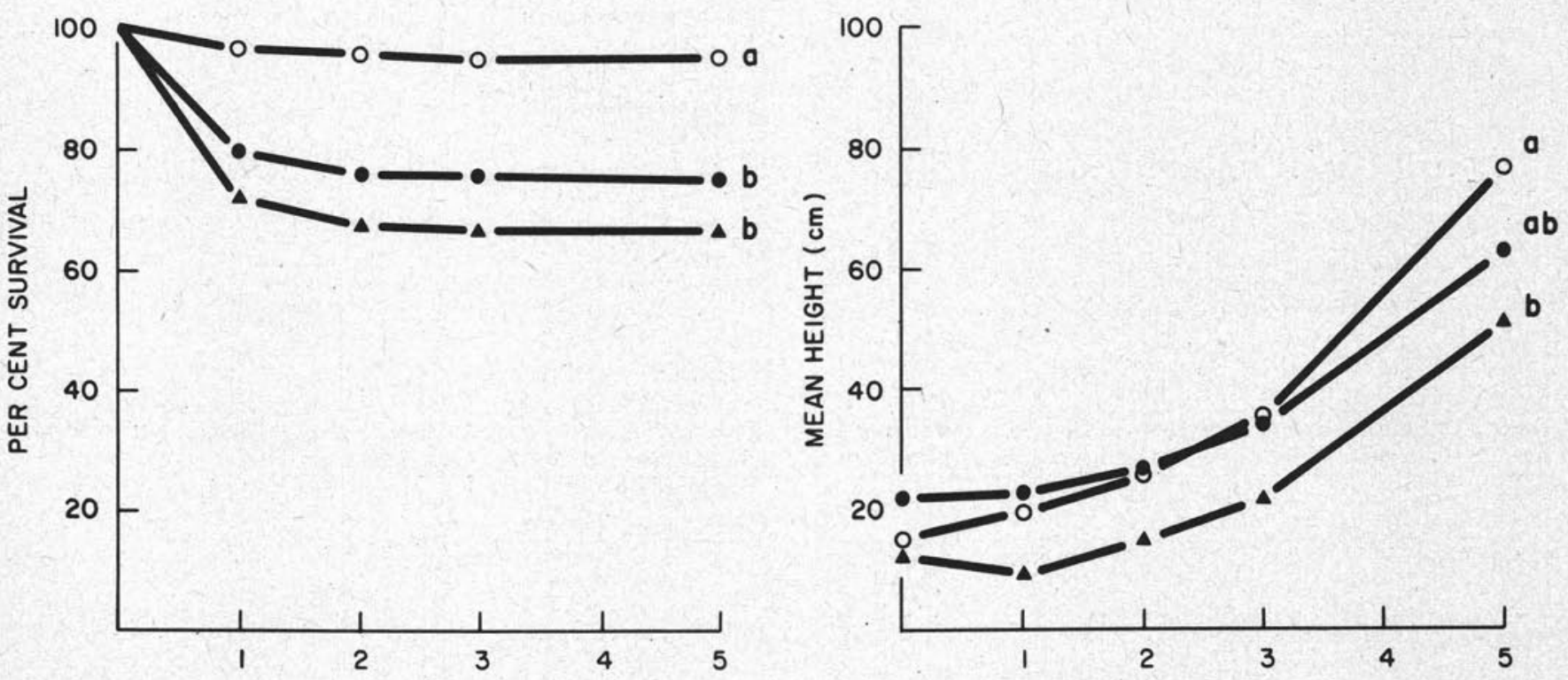

YEARS FROM PLANTING

Fig. 1. Survival and growth of Douglas-fir and western hemlock on the north aspect at Robertson River; points followed by the same letter at year 5 are not significantly different $(p=.05)$. 

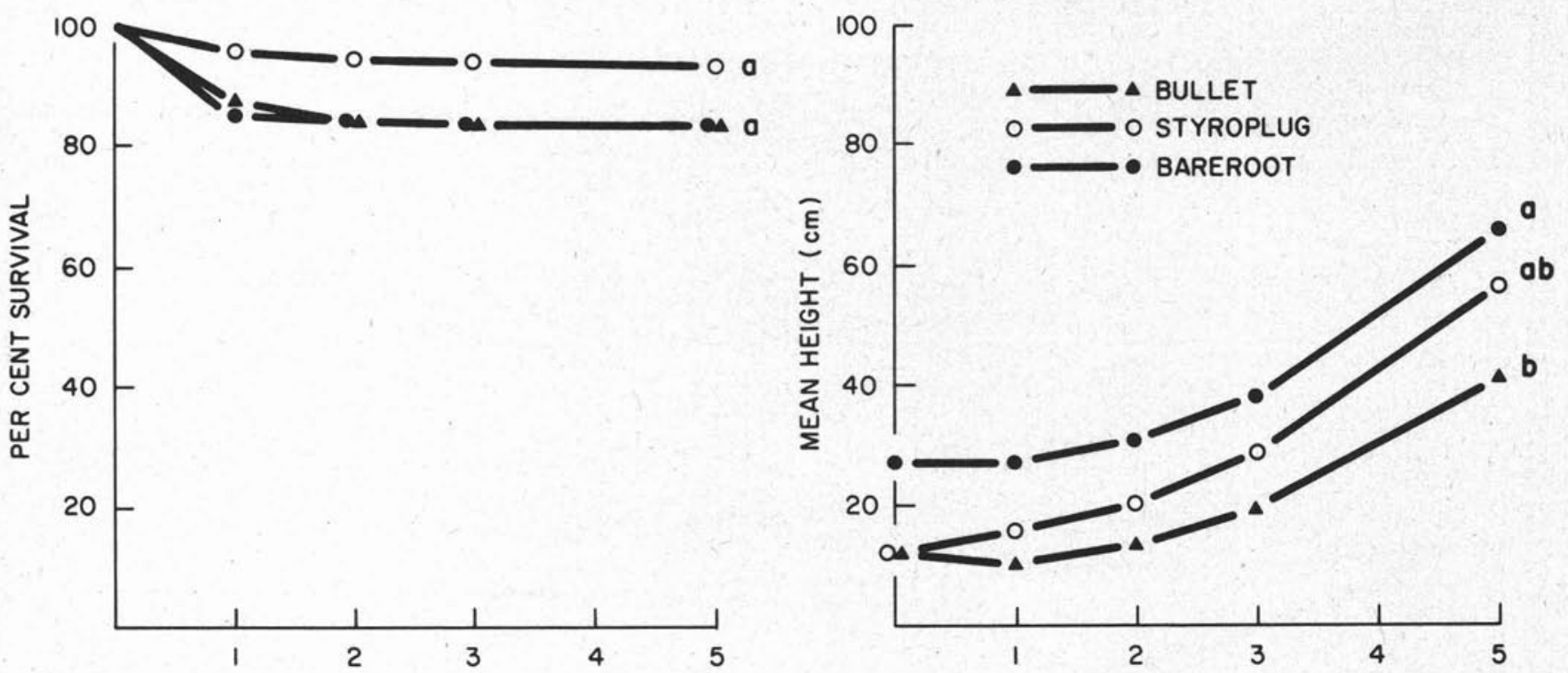

\section{DOUGLAS-FIR : LEECH ( SOUTH)}
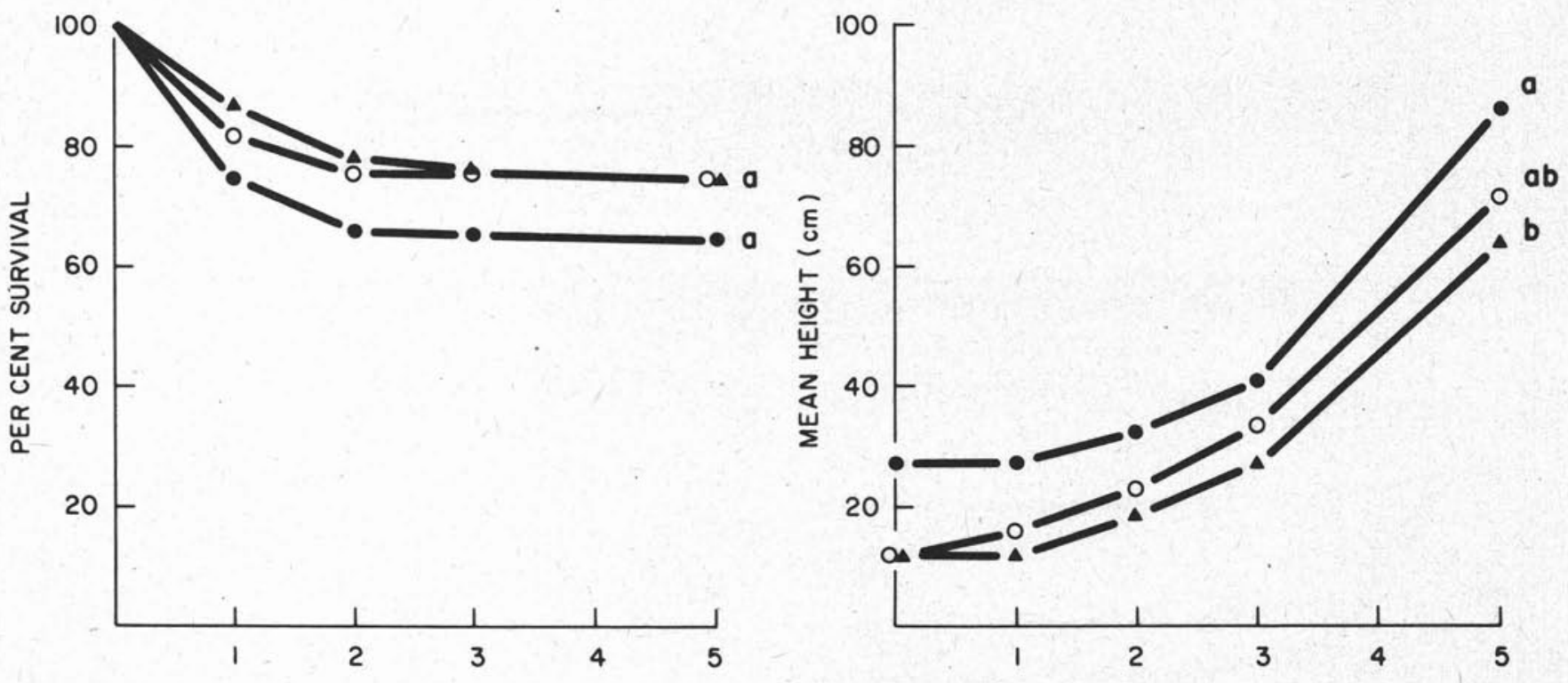

YEARS FROM PLANTING

Fig. 2. Survival and growth of Douglas-fir on two aspects at Leech River; points followed by the same letter at year 5 are not significantly different $(p=.05)$.

Table 2. Significance of differences in survival and mean seedling height after 5 growing seasons by stock types, aspect and year of outplanting for Douglas-fir and western hemlock at the Leech and Robertson River areas.

\begin{tabular}{|c|c|c|c|c|c|}
\hline Area & Factors & \multicolumn{2}{|c|}{ Douglas-fir } & \multicolumn{2}{|c|}{ Western hemlock } \\
\hline Leech River & North vs. South Aspect & $\star \star 3$ & 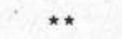 & $\star \star$ & $\star \star$ \\
\hline Robertson River & Type of Stock & $\star *$ & $\star 2$ & $\star \star \star$ & $\star$ \\
\hline . & $\begin{array}{l}\text { Year of Outplanting } \\
\text { North vs. South Aspect }{ }^{4}\end{array}$ & $\star \star *$ & NS & $\star \star \star$ & NS \\
\hline
\end{tabular}

2 Not significant

3Significant $(p<\overline{<} .01)$

${ }^{4}$ South aspect plots destroyed by fire 
First year survival rates for the styroplug seedlings outplanted in 1972 and 1973 were 32 and $91 \%$, respectively. High first-year mortality in 1972 was the result of the seedlings being under extreme moisture stress, as they were in an advanced state of flush by the time planting could be done in May. As mentioned previously, delayed planting was caused by late snow melt from the site and the seedlings had not been held in cold storage.

Differences in seedling survival between stock types were not significant at Leech River (Table 2; Fig. 2). Styroplug seedling survival was equal to, or better, than, bareroot stock, depending upon the aspect of the plantation, which had a significant effect on survival rates (Table 2).
Higher survival was obtained on the north aspect, where conditions of soil moisture and exposure were less extreme. The earlier planting dates realized at each area in 1973 significantly increased survival rates of all stock types (Table 2). In coastal British Columbia, the frequency and amount of rainfall declines sharply after March and spring planting must be done as soon as ground conditions allow. However, on mid- to high-elevation sites $(>640 \mathrm{~m})$, planting can be greatly delayed by late spring snow fall and/or slow snow melt. Seedling growth at both areas was significantly dependent on what type of stock was planted (Table 2). The larger 2-year-old bareroot stock always outgrew the smaller 1 -year-old container grown seedlings in the field (Figs. 1 and
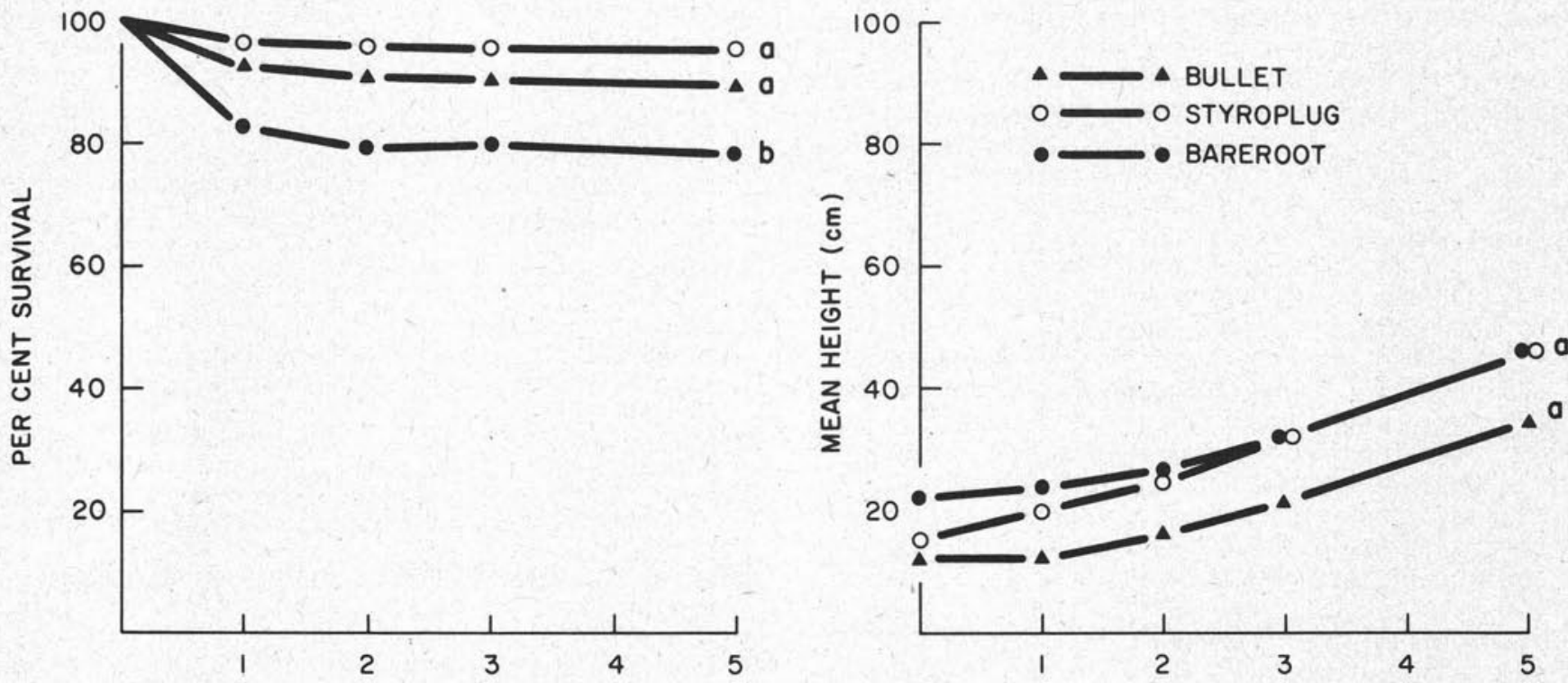

WESTERN HEMLOCK : LEECH ( SOUTH)
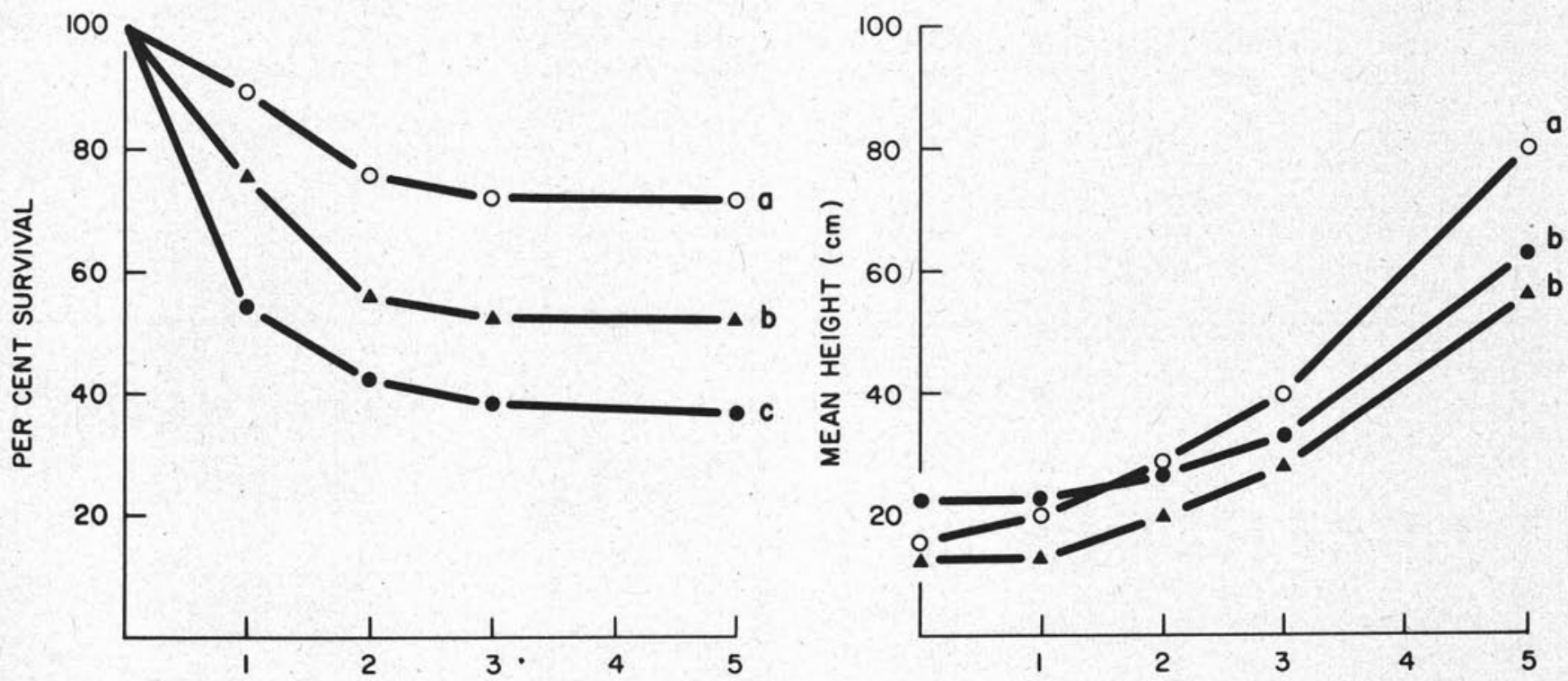

YEARS FROM PLANTING

Fig. 3. Survival and growth of western hemlock on two aspects at Leech River; points followed by the same letter at year 5 are not significantly different $(p=.05)$. 
2). Five years after outplanting, the height of the bareroot seedlings was significantly greater than that of the bullet seedlings but not significantly greater than that of the styroplug seedlings at Leech River. Total height of seedlings planted in bullets was always less than that of styroplug seedlings. This is the result of planting a smaller seedling (Table 1) whose initial root growth was also restricted by the rigid, plastic container wall. Significantly better growth of all stock types was achieved on the south aspect at Leech River (Table 2), where there was more ground seepage moisture than on the north aspect.

\section{Western hemlock}

Best survival rates among the western hemlock stock types was realized with the styroplug seedlings. Their fifthyear survival rate was always significantly greater than bareroot seedlings (Figs. 1 and 3). Styroplug seedlings survival was also significantly greater than that of bullet seedlings, except on the north aspect at Leech River (Fig. 3). Differences in survival were greater on the south aspect (Fig. $3)$, highlighting the advantages to be gained in planting plug western hemlock seedlings where there are greater extremes in temperature and where soil surface horizons dry out quickly. Ecologically, western hemlock is well-suited to the montane wetter maritime coastral western hemlock variant at Robertson River. Styroplug seedling survival there after five growing seasons was $95 \%$ (Fig. 1).

Western hemlock is not the proper species choice for the south aspect slopes at Leech River in the drier maritime coastal western hemlock zone, particularly if bareroot stock is used (Fig. 3). However, this adverse effect can be modified by using container-grown stock such as the styroplug seedling, which significantly improved the survival rate by $36 \%$. Reduced disturbance of the plug seedling's root system at the time of planting is thought to be the contributing factor for this improvement.

Year of outplanting created no significant differences in survival or growth at Leech River, but did affect survival rates at Robertson River (Table 2). Again, this was due to the delay in planting at Robertson River until May 1972, which resulted in significantly lower survival rates for bullet and bareroot stock. Styroplug seedling survival was not influenced by the year-of-outplanting effect. Evidently, this stock type allows a greater degree of flexibility in planting operations, allowing seedlings to be planted later in the spring than bareroot stock without a significant drop in seedling survival.

Mean height of styroplug seedlings was usually significantly greater than bareroot stock (Figs. 1 and 3). As with Douglas-fir, styroplug seedling growth was always greater than that of the bullet seedling, indicating that the smaller initial seedling size attainable in the $11-\mathrm{cm}$ bullet and the rigid container wall does have a negative effect on seedling performance.

In conclusion, the greatest gains in field performance

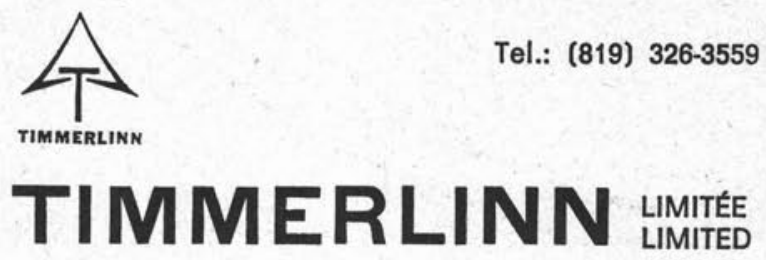

PROFESSIONAL AND TECHNICAL SERVICES IN FORESTRY AND ENVIRONMENTAL SCIENCES

R.R. No. 2, STE. AGATHE DES MONTS, QUE. J8C $2 Z 8$ were achieved by using 1-0 styroplug seedlings for western hemlock. Such conclusions were strengthened by the low occurence of significant year-of-outplanting effects for the hemlock stock categories. These gains are not so evident for Douglas-fir, where conventional $2-0$ bareroot stock also survived at similar rates to styroplug stock. Furthermore, the older, larger 2-0 bareroot seedlings are always taller than the 1-0 container seedlings throughout the first 5 years after planting - an important consideration where deer browsing is a problem, as it often is on cutover areas on Vancouver Island. Styroplug seedling survival and growth was always greater than that of bullet seedlings. The smaller bullet seedling, planted in a rigid-walled container, did have a negative effect on seedling performance in the field, substantiating conclusions derived from similar research at lower elevation sites in Coastal British Columbia (Arnott 1975).

\section{Acknowledgments}

The author expresses his appreciation to the British Columbia Ministry of Forests for supplying tree seed and bareroot nursery stock and to Pacific Forest Products Ltd. for providing the experimental sites. Thanks are extended to G.D. Nixon, G.G. Goodmanson and $\mathrm{D}$. Beddows for technical assistance throughtout the program, and J.C. Wiens for the graphics.

\section{References}

Arnott, J.T. 1971. Progress report on field performance of Douglasfir and western hemlock container seedlings on Vancouver Island, British Columbia. Can. For. Serv., Victoria, B.C. Inf. Rep. BC-X-63.

Arnott, J.T. 1973. Evolution of the styroblock reforestation concept in British Columbia. Commonw. For. Rev. 52:72-78.

Arnott, J.I. 1975. Field performance of container-grown and barefoot trees in coastal British Columbia. Can. J. For. Res. 5: 186-194.

Klinka, K., F.C. Nuszdorfer and L. Skoda. 1979. Biogeoclimatic units of central and southern Vancouver Island. B.C. Min. Forests. Victoria, B.C

Korelus, V.J. and T. Lewis. 1976. Biophysical mapping of Cowichan Division-South, Pacific Logging Company Ltd., Victoria, B.C.

Roemer, H.L. and V.J. Korelus. 1975. Biophysical mapping of Sooke Division, Pacific Logging Company Ltd., Victoria, B.C.

Sjoberg, N.E. 1974. The styroblock container system. In Proc. North Amer. Containerized forest tree seedling Symposium. Ed. Tinus et al., Great Plains Agric. Counc. Publ. 68, 217-228.

Steel, R.G.D. and J.H. Torrie. 1960. Principles and procedures of statistics. McGraw-Hill, N.Y.

Van Den Driessche, R. 1969. Forest nursery handbook. B.C. For. Serv., Victoria, B.C. Res. Note 48.

Van Eerden, E. 1974. Growing season production of western conifers. In Proc. North Amer. Containerized forest tree seedling symposium. Ed. Tinus et al. Great Plains Agric. Counc. Publ. 68, 93-103.

Walters, J. 1969. Container planting of Douglas-fir. For. Prod. J. 19(10): 10-14.

\section{R.R. NO. 2, STE. AGATHE DES MONTS, QUE. JBC $2 Z 8$}

